\title{
KRAJOBRAZ \\ JAKO PRZEDMIOT DOŚWIADCZANIA W GEOGRAFII I KRAJOZNAWSTWIE
}

\section{Wstęp}

A. de Saint-Exupéry w Małym Księciu - powiastce filozoficznej o uniwersalnym przesłaniu i wyjątkowej popularności - wykreował postać geografa. Żyje on na szóstej z kolei planecie odwiedzonej przez głównego bohatera, poszukującego prawdziwej miłości i wielkiej przyjaźni. Jest to typ człowieka, który interesuje się jedynie światem rzeczy, których osobiście nie doświadczył (Dziewiecki, 2013). Jego zadaniem jest liczenie miast, rzek, gór, oceanów i pustyń. Jest on „zbyt ważną osobistościa, aby mógł pozwolić sobie na łazikowanie" (Saint-Exupéry, 2013, s. 54). Nie opuszcza swego biura, ale przyjmuje badaczy, wypytuje ich i notuje to, co mówią. Stara się, aby rzeczy zapisywane w jego księgach były imponujące i niezmienne. Nanosi na mapę swoich wyobrażeń wysokie szczyty, których nigdy nie zdobył, albo wielkie morza, których nigdy nie przepłynął. Róża Małego Księcia, ze względu na swoją efemeryczność, nie ma dla geografa żadnego znaczenia. W jego przekonaniu nie zasługuje ona na to, aby ktoś przejmował się jej losem. $Z$ tego samego powodu na mapach geografa nie ma ludzi. Są oni bowiem zbyt mali i zbyt podatni na śmierć. Bohater powiastki jest oderwany od przemijającej codzienności, interesują go tylko trwałe obiekty - zlicza je i opisuje ich lokalizację i parametry, czerpiąc wiedzę tylko z relacji świadków o nieskazitelnej moralności. Geograf symbolizuje zatem tych, których fascynują „wielkie rzeczy", na tyle odległe, aby nie musieli mierzyć się z trudem wyjścia im na spotkanie (Dziewiecki, 2013).

Przedstawiony przykład, choć odzwierciedla przede wszystkim indywidualne wyobrażenia A. de Saint-Exupéry, może także być 
egzemplifikacją sposobu postrzegania geografii przez osoby z zewnątrz. Wilczyński (2011) zauważył, że jest ona oceniana jako popularna wiedza o wszystkim i jednocześnie o niczym (czyli zbędna), a z drugiej strony cieszy się sympatią społeczeństwa. Jednak wcześniej ten sam autor stwierdzil, że:

geografia jest chyba jedyną dziedziną wiedzy, która byłaby w stanie skutecznie zintegrować rozbiegane wątki naszej wiedzy, stworzyć fundament poczucia jedności wszystkich ziemskich rzeczy: człowieka i przyrody; świadomości i materii; podmiotu i przedmiotu - poczucia, że wszystko może być ze sobą zharmonizowane (Wilczyński, 1996, s. 99-100).

Podobny pogląd zaprezentował Wojciechowski (1999, s. 43), pisząc, że „dla dalszej współczesnej cywilizacji geografia jest nauką podstawowa, istotną na każdym poziomie wykształcenia, umożliwiającą rozumienie świata". Gdzie zatem można doszukiwać się przyczyn niezrozumienia przez społeczeństwo roli geografii we współczesnym świecie? Czy jedną z nich jest oddalenie tej nauki od perspektywy człowieka, który codziennie może poznawać piękno krajobrazów i zachwycać się nim? W opinii autora poznanie geograficzne, którego efektem jest „rozumienie świata” wymaga bezpośredniego doświadczenia konkretnego krajobrazu ${ }^{1}$, a nie tylko zbierania informacji dostarczanych przez tych, którzy już to przeżyli. Podobnie można przyjąć, że doświadczanie krajobrazu odgrywa ważną rolę także w krajoznawstwie, wprawdzie nieuznawanym za naukę, jednak bliskim geografii, mogącym ją wspierać.

${ }^{1}$ Słowo „krajobraz” w języku potocznym rozumiane jest najczęściej jako widok lub otaczający obszar. W nauce natomiast „krajobraz” interpretuje się jako zestaw obiektów realnie istniejących, system powiązanych ze sobą procesów, zbiór bodźców oddziaływających na różne zmysły ludzkie (w tym zestaw widoków), zbiór wartości oraz system świadczący rzeczywiste i potencjalne usługi dla różnych grup użytkowników (Richling, Solon, 2011). W wielu publikacjach z zakresu geografii humanistycznej podkreśla się, że krajobraz jest związany z percepcją. Relph (1989) interpretował krajobraz jako wizualną postać regionu, która nieodłącznie towarzyszy egzystencji człowieka, tworząc rodzaj tła: jest zawsze obecna, widoczna, chociaż umykająca uwadze, i stanowi nieodłączny aspekt naszego „bycia-w-świecie”. Dla Tuana (1979) krajobraz to pewna zintegrowana całość, która powstaje poprzez wysiłek wyobraźni na podstawie wysoko wyselekcjonowanego zestawu danych zmysłowych; jest produktem dojrzałego umysłu. Wojciechowski (1986, s. 32) zwrócił uwagę na to, że „krajobraz jest fizjonomia, wyrazem zewnętrznym środowiska geograficznego, a oceniany i wartościowany jest jako synteza zintegrowanych postrzeżeń, widoków i związanych z nim różnorodnych odczuć zmysłowych oraz odpowiednich asocjacji i struktur zakodowanych w umyśle obserwatora". Bartkowski (1985) zauważył, że krajobraz jest określany przez ludzkie postrzeganie, dlatego uznaje się go za rzeczywistość geograficzno-psychologiczną. 
Celem artykułu jest wykazanie ważnej roli doświadczania krajobrazu w geografii i krajoznawstwie. W toku rozważań, po przedstawieniu relacji krajoznawstwa i geografii, scharakteryzowano problematykę percepcji krajobrazu. Następnie opisano przykładowe zagadnienie (organy w krajobrazie), w odniesieniu do którego doświadczanie krajobrazu jest bardzo istotne. Artykuł ma charakter przeglądowy, oparto go głównie na analizie literatury naukowej. Dodatkowo wykorzystano w nim własne doświadczenia z ponad 20-letniej pracy w zawodzie geografa - badacza i nauczyciela, a jednocześnie wieloletniego turysty-krajoznawcy.

\section{Krajoznawstwo a geografia}

Na temat związku krajoznawstwa z geografią wypowiedzieli się już ponad 100 lat temu L. Sawicki i W. Nałkowski. Pierwszy z nich pisał, że zarówno krajoznawstwo, jak i geografia „badają krajobraz w głębszem tego słowa znaczeniu" (Sawicki, 1909, s. 4). Krajoznawstwo, rozumiane jako „dział pochodny” geografii, szuka zrozumienia krajobrazu „,w obrębie pewnej części kuli ziemskiej” (Sawicki, 1909, s. 4). Autor ten zauważa również, że "geografia odkrywa prawa ogólne, krajoznawstwo tylko prawa, ważne dla danego kraju" (Sawicki, 1909, s. 13) oraz że "geografia opiera się na doświadczeniach zrobionych w poszczególnych częściach ziemi, więc na materiale krajoznawczym" (Sawicki, 1909, s. 13). Krajoznawstwo jest zatem podstawą i "tą częścią geografii, która jest pełna życia i która nigdy nie skostnieje w szablonach" (Sawicki, 1909, s. 15). Swoje rozważania kończy życzeniem: „Niech sobie więc krajoznawstwo a geografia zawsze podają bratnią dłoń, aby wspólnemi siłami dopiąć wspólnego celu, odtworzenia głębszego związku wszelkich zjawisk na powierzchni ziemi" (Sawicki, 1909, s. 15).

W. Nałkowski, nawiązując do artykułu L. Sawickiego, zwrócił uwagę, że krajoznawstwo nie jest ani geografią szczegółową, ani geografią malownicza, ani „,encyklopedyą geograficzną", „nie jest nauką, lecz zbiorem wszelkich możliwych faktów, napotykanych w danym kraju" (Nałkowski, 1910, s. 19). Zauważa też, że ",geograf nie koniecznie musi być podróżnikiem" (Nałkowski, 1910, s. 12). Jeśli posiada naukowe przygotowanie, zmysł geograficzny i intuicję, to jest w stanie doskonale opisać geografię kraju, którego nigdy nie widział. Bezpośrednie doświadczenie może jednak pomóc w odkryciu nowych związków, których wcześniej nie dostrzegł. Nałkowski podkreślał ważność pracy geografa, który jako obejmujący całość, ma obowiązek „zsyntetyzowania jej [pracy - przyp. S.B.], zużytkowania odpowiedniego 
dla celów całości" (Nałkowski, 1910, s. 15). Geografia opiera się zatem na zrozumieniu naukowym, czerpiącym z krajoznawstwa jako ze źródła.

W XXI w. krajoznawstwo i geografia nadal pozostają w bliskich relacjach. Łączy je m.in. doświadczanie krajobrazu, które choć może się różnić w szczegółach, to powinno być ważnym elementem poznania wyjątkowości danego miejsca. Stasiak, Włodarczyk i Śledzińska (2016) twierdza, że istotą nowoczesnego krajoznawstwa jest interpretacja dziedzictwa obszaru (miejscowości, regionu, kraju), odkrywanie genius loci, odsłanianie ukrytego dla laika sensu zjawisk, wyjaśnianie genezy obiektów i wydarzeń oraz związków przyczynowo-skutkowych. Podkreślają też bardzo ważną rolę umiejętności „czytania krajobrazu” oraz wieloaspektowego doświadczania, "przeżywania” kraju. Dzisiejsze krajoznawstwo powinno być zatem multisensoryczne, nasycone emocjami, interakcyjne, przygodowe, multimedialne, czyli „,nowoczesne w formie, ale tradycyjne w treści" (Stasiak, Włodarczyk, Śledzińska, 2016, s. 25).

\section{Percepcja (doświadczanie) krajobrazu}

Percepcja według Tuana (1987) jest kombinacją uczuć i myśli. Wnioski z odbioru perceptualno-zmysłowego stają się częścią poznania rozumowego. „Aktywna, refleksyjna myśl jest częścią mechanizmu uruchamiającego wszystkie zmysły i umysł, prowadzącego do totalnego, całościowego doświadczania przedmiotu lub miejsca. Światy umysłowe wynikają z przetworzenia doświadczeń zmysłowych i ruchowych, przy czym sprawność przestrzenna wyprzedza tu wiedzę" (Tuan, 1987, s. 31). Według Wojciechowskiego (1994) percepcja krajobrazu jest razem z doświadczaniem miejsca elementem postrzegania środowiska, rozumianym jako proces przetwarzania w umyśle człowieka bodźców docierających $\mathrm{z}$ otoczenia, istotny w tworzeniu postaw, stanów emocjonalnych i wiedzy, a także w tworzeniu wyobrażenia, czyli zakodowanej w umyśle pewnej struktury - syntezy. Percepcja zależy od wielu czynników, m.in.: bezpośredniej informacji, wcześniejszych doświadczeń (filtry percepcyjne) i kontekstu przestrzennego. Poprzez procesy percepcji człowiek poznaje i wartościuje krajobraz (Wojciechowski, 1994).

Tuan (1987) zauważył, że krajobrazu doświadczamy w sposób totalny, czyli wszystkimi zmysłami oraz aktywna, refleksyjną myślą. Choć organizacja ludzkiej przestrzeni zależy prawie wyłącznie od wzroku, pozostałe zmysły rozszerzają i wzbogacają przestrzeń wizualną. Podobny pogląd głosi Rodaway (1994), podkreślając, że doświadczenie wizualne 
jest warunkiem wstępnym szerszego, multisensorycznego rozumienia krajobrazu. W krajobrazie nie jesteśmy biernymi odbiorcami widoków, lecz aktywnymi uczestnikami angażującymi wszystkie zmysły, pełnimy funkcję czującego, doznającego ciała.

Krajobraz, postrzegany przez człowieka na podstawie odczuć zmysłowych wywoływanych przez bezpośrednie otoczenie, stał się przedmiotem zainteresowania geografa Granö (1997) na początku XX w. Strefa dalekiego widoku (tło) oraz najbliższe otoczenie są według niego składowymi świata postrzeganego i odczuwanego. W strefie dalekiego widoku człowiek odbiera prawie wyłącznie bodźce wzrokowe, natomiast w najbliższym otoczeniu dociera do niego większość bodźców słuchowych i zapachowych. Wewnątrz tej strefy odczuwana jest też temperatura powietrza i podłoża, ich wilgotność, faktura gruntu oraz bodźce smakowe. Elementy te stanowią środowiskową składową poczucia miejsca i mogą zostać przetworzone na odczucie "ducha miejsca”. Tak rozumiane najbliższe otoczenie tworzy kontekst percepcji krajobrazu (Wojciechowski, 2008).

Należy podkreślić, że już w latach 80. XX w. Bartkowski (1985) zauważył, że możliwość badań krajobrazu, nie tylko widzialnego, daje nowe perspektywy rozwoju nie wyłącznie samej ekologii krajobrazu, ale także ochrony i kształtowania środowiska oraz planowania przestrzennego. Stworzona przez tego badacza koncepcja krajobrazów multisensorycznych stała się tematem kilku monografii (m.in. Kowalczyk, 1992). Według Kowalczyk (2008) badanie percepcji krajobrazu polega na ocenie odczuć - emocji (stanów psychicznych), wywołanych cechami elementów krajobrazu oraz zjawiskami w nim występującymi i postrzeganymi poszczególnymi zmysłami: wzrokiem, słuchem, węchem i dotykiem.

Multisensoryczność percepcji jest także dostrzegana w innych dyscyplinach. Według Frydryczak (2013) w relacji z krajobrazem wykrystalizowały się dwa rodzaje doświadczeń: spojrzenie panoramiczne, związane z tradycyjnym, estetycznym sensem krajobrazu oraz doświadczenie topograficzne, odpowiadające procesualnej naturze krajobrazu. Różnica między nimi ujawnia się w sytuacji „bycia wobec krajobrazu” lub „bycia w krajobrazie". Pierwsza z nich akcentuje przewagę wzroku doświadczonego w rozpoznawaniu widoków i ujmowaniu ich w ramy, druga zaś detronizuje go, aktywizując pozostałe zmysły, wobec których widzenie jest formą konfrontowania, uzupełnienia impulsów i bodźców napływających z zewnątrz. „Bycie w krajobrazie” to zatem przeżycie cielesne, które angażuje wszystkie zmysły. W doświadczeniu topograficznym wzrok jest zatem pomocniczy, pozwala nam ocenić sytuację, ale nie umożliwi nam odczucia pełnej jakości krajobrazu: polifonii dźwięków, zapachów i smaków. Jako 
multisensoryczne, doświadczenie topograficzne, najpełniej kształtowane $\mathrm{w}$ drodze, staje się medium, przez które zaznajemy świata i organizujemy go. Spojrzenie panoramiczne wykształciło natomiast umiejętność patrzenia na krajobraz jak na niezmienny, trwały obraz, powiązany z punktem widokowym (Frydryczak, 2013). Za pośrednictwem punktu widokowego ustanawiany jest związek nadrzędności i podrzędności w relacji między widokiem a przedmiotem widzenia (Cosgrove, 2003).

Zaznaczyć należy, że związek percepcji z krajobrazem podkreśla także Europejska Konwencja Krajobrazowa, definiując krajobraz jako „obszar postrzegany przez ludzi, którego charakter jest wynikiem działalności i interakcji czynników przyrodniczych i/lub ludzkich" (Europejska Konwencja..., 2000 , s. 3). Krajobraz jest doświadczany powszechnie, wpływa zatem na jakość życia ludzi wszędzie tam, gdzie przebywają: w mieście i na wsi, na obszarach cennych przyrodniczo i zdegradowanych, w miejscach szczególnych i zwyczajnych - „codziennych". Jak dowodzą raporty uzupełniające Europejskiej Konwencji Krajobrazowej, percepcja krajobrazu ma charakter multisensoryczny. Dźwięk i zapach, a także dotyk i smak przyczyniają się do pozytywnej lub negatywnej całościowej oceny krajobrazów przez człowieka i wpływają na standard życia (zob. m.in. Landscapes and individual and social well-being, 2003). Krajobraz wzbogaca i rozwija doświadczenia sensoryczne. Ubóstwo doznań wiąże się z obniżeniem jakości życia. Za podstawowy cel Europejskiej Konwencji Krajobrazowej uznano przyczynienie się do rozwoju krajobrazów o wysokiej wartości, w celu poprawy jakości życia mieszkańców Europy (Landscape and sustainable development, 2006).

\section{Organy w krajobrazie}

Organy są instrumentem dętym klawiszowym, który składa się z szafy (w tym widocznego prospektu), dużej liczby piszczałek wydających dźwięki o różnej wysokości i barwie, traktury, stołu gry i systemu doprowadzającego powietrze. Nazywane są królem instrumentów dzięki wielu "królewskim przymiotom”, takim jak: monumentalne rozmiary, niezwykłe kształty i ozdoby wzniesione na dekorowanej emporze (niczym na wysokim tronie), niezwykłe walory brzmieniowe (najszersza skala wysokości dźwięków, najbogatsza paleta barw, największe możliwości dynamiczne) - przez co stają się tajemnicze, budzą zainteresowanie, cieszą oczy i uszy. Są jednocześnie instrumentem bardzo starym, znanym już w starożytności, i nadal pozostają ważnym elementem wyposażenia wielu zabytkowychi współczesnych obiektów sakralnych (fot. 1) oraz sal 
koncertowych (fot. 2). Dzieła różnych kompozytorów powstawały z myślą o wykonywaniu ich na największym instrumencie muzycznym. Sobór Watykański II organom jako tradycyjnemu instrumentowi muzycznemu, „którego brzmienie ceremoniom kościelnym dodaje majestatu, a umysły wiernych podnosi do Boga i spraw niebieskich", przypisał szczególne miejsce w kościele (Konstytucja o liturgii świętej, 2020). Dla geografa ważny jest przestrzenny aspekt tego instrumentu, na który zwrócił uwagę Pociej (1995, s. 84) w następujących słowach:

Organy są instrumentem wkomponowanym w realną przestrzeń, wnętrze architektoniczne kościoła. Rozległość, rozciągłość, szerokość, objętość - to cechy zasadnicze ich uniwersum dźwiękowego. Z brzmień wszystkich instrumentów brzmienie organowe kojarzy się nam najbardziej z kształtem wizualnym, plastyczną bryła, budulcem architektonicznym; z takiego brzmienia - surowca dźwiękowego - można wręcz muzykę budować, wznosić ją i rozprzestrzeniać na podobieństwo dzieła architektury: filary, łuki, wiązania; ściany, sklepienia; fundamenty i zwieńczenia.

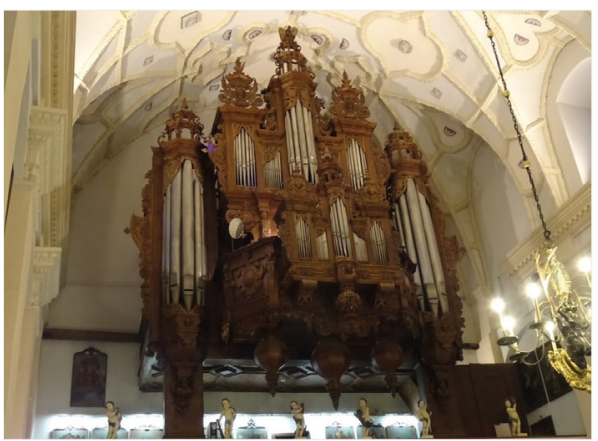

Fotografia 1. Organy w kościele farnym w Kazimierzu Dolnym Źródło: S. Bernat

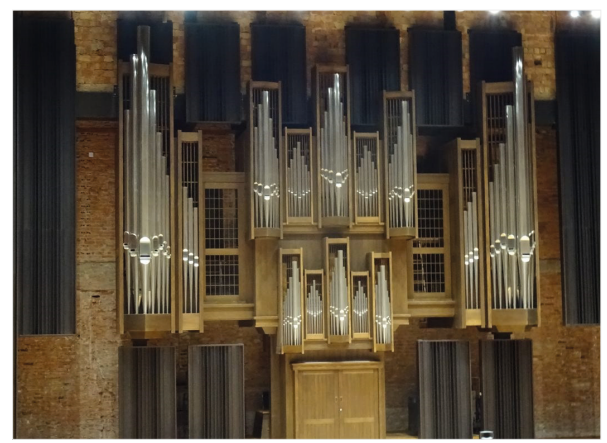

Fotografia 2. Organy w Filharmonii Lubelskiej Źródło: S. Bernat

Z punktu widzenia zarówno krajoznawcy, jak i geografa przedmiotem zainteresowania mogą być nie tylko organy jako instrument związany $z$ konkretnymi miejscami ${ }^{2}$, ale także obiekty w krajobrazie nazwane organami, z uwagi na podobieństwo ich kształtu do prospektu organowego. Krajobraz posiada bowiem także znaczenie symboliczne - jest niejako tekstem, który może być różnie odczytywany i interpretowany w procesie percepcji. Krajobrazy sformułowane w pojęcia stają się zjawiskami

${ }^{2}$ Każdy instrument jest inny, ale są pewne prawidłowości w lokalizacji organów o podobnej stylistyce brzmieniowej. 
kultury, podlegają dziedziczeniu, ewolucji, przemianom, stanowiąc część duchowego czy intelektualnego dorobku ludzkości (Kolbuszewski, 1985). Nie powinno zatem wywoływać zaskoczenia nazywanie obiektów obecnych w krajobrazie pojęciami muzycznymi. Muzyka jest bowiem tym, co tkwi w każdym z nas. Za jej pośrednictwem można doskonale wyrazić uczucia, przemówić do odbiorców.

Od dawna w terminologii geograficznej i geologicznej funkcjonuje pojęcie „organów geologicznych”. Kunsky (1956) obejmuje tym określeniem formy krasu kopalnego - kieszenie, jamy, kominy, szczeliny, studnie, powstające pod pokrywą osadów niekrasowych, przez rozpuszczanie skał krasowych, przeważnie marglistych i ilastych wapieni, szczególnie kredowych. Dalej wskazuje on, że organy geologiczne są zwykle widoczne w odsłoniętych ścianach łomów, rzadko na wcięciach dolinnych, na powierzchni ziemi zaś ukazują się dopiero wtedy, gdy ich niekrasowa pokrywa zostaje zdenudowana, i stają się wówczas podobne do żeber i lejków krasowych. Formy te osiągają do ok. 10 m głębokości i $20 \mathrm{~m}$ szerokości. Pulina (1999) zalicza organy geologiczne do mikroform krasowych przykrytych. Są one pospolite m.in. w skałach wieku kredowego w okolicach Londynu, w Basenie Paryskim, na Zelandii (Dania), w wapieniach triasowych w okolicach Berlina, w gipsach górnego permu na południowych zboczach Harzu, w wapieniach i dolomitach Jury Frankońskiej, w wapieniach paleozoicznych krasu czeskiego, w wapieniach koralowych Bermudów i południowej Australii (Kunsky, 1956).

Również w Polsce, badając kras kopalny, naukowcy doszukali się form typu „organy geologiczne” w kilkudziesięciu miejscach, głównie na Lubelszczyźnie i Wyżynie Krakowsko-Częstochowskiej. Maruszczak (1964) opisał organy geologiczne w Kocudzy (okolice Frampola) na Roztoczu, będące młodszą generacją form krasowych o wielkości do 3 m głębokości i kilku decymetrów średnicy, wypełnionych tłustą gliną, reprezentującą produkt degradacji wapienia, oraz zwietrzałymi utworami piaszczystymi ze żwirami. W Mielniku nad Bugiem, położonym w obrębie Podlaskiego Przełomu Bugu, organy geologiczne, które rozpoznaje Drzał (1961), to kilkanaście kieszeni i jam o rozmiarach do 2 m długości i 0,6 m szerokości, wypełnionych materiałem ilastym z domieszką piasku i okruchów skał krystalicznych oraz mieszaniną pyłków drzew i roślin zielnych. Natomiast w sąsiedniej Kornicy k. Mielnika Wójcik (1959) opisał organy geologiczne, odnosząc to określenie do lejów i kominów krasowych, wypełnionych głównie iłami rezydualnymi koloru czerwonego oraz piaskami glaukonitowymi z konkrecjami fosforytowymi. Również w położonym w centralnej części Lubelszczyzny Rejowcu na Pagórach Chełmskich 
rozpoznano kieszeniowate jamy, zapełnione osadami czwartorzędowymi, zwane organami geologicznymi. Występowanie ich uzależnione jest od litologii i spękań w kredzie (Rzechowski, 1962).

W krajobrazie Polski spotykamy „organy" także w postaci nazw własnych obiektów, będących genetycznie różnymi formami rzeźby (mikrorzeźby). Nazwy te zostały nadane najprawdopodobniej przez miejscową ludność, a następnie utrwaliły się w tradycji ludowej. W związku z tym wprowadzono pojęcie organów geomorfologicznych i podjęto próbę zdefiniowania i sklasyfikowania tego typu form według procesu odpowiadającego za ich utworzenie. Konieczne jest jednak podkreślenie, że z wyjątkiem organów krasowych (geologicznych) nie zawsze i nie wszędzie obiekty o wskazanych cechach (fizjonomii) są określane jako organy.

Organy geomorfologiczne są formą mezo- i mikroreliefu powierzchni Ziemi, charakteryzującą się obecnością sąsiadujących ze sobą, stromych form wypukłych w postaci słupów, żeber i przedzielających je form wklęsłych (Bernat, 2001). Występują najczęściej w obrębie ścian skalnych, choć spotykane są także w postaci odrębnych form. Powstanie organów geomorfologicznych wiąże się zarówno z procesami egzo- (kras, wietrzenie), jak i endogenicznymi (plutonizm, wulkanizm, ruchy orogeniczne). Odsłonięcie ich na powierzchni jest najczęściej spowodowane bezpośrednią działalnością człowieka.

W klasyfikacji organów geomorfologicznych, według procesu odpowiadającego za ich utworzenie, wyróżniono:

- organy krasowe (geologiczne) - kieszeniowato-kominowate formy podpowierzchniowe powstałe $\mathrm{w}$ wyniku podpokrywowego wietrzenia krasowego (ługowania $\mathrm{CaCO}_{3}$ ). Wypełnione tłustą gliną reprezentującą produkt degradacji wapienia oraz zwietrzałymi utworami piaszczystymi ze

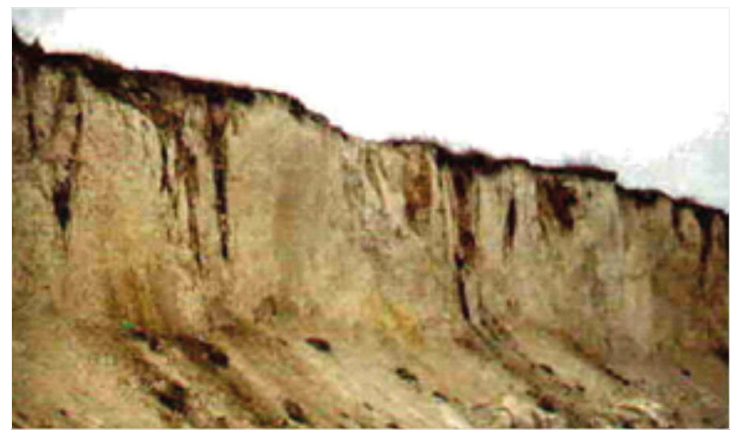

Fotografia 3. Organy geologiczne (Wyżyna Lubelska, okolice Frempola) Źródło: S. Bernat 
żwirami. Charakterystycznem.in. dla strefy krawędziowej Roztocza w okolicy Frampola (Drzał, 1961; Maruszczak, 1964; Rzechowski, 1962) (fot. 3).

- organy wulkaniczne (krystalizacja magmy) - układ słupów powstałych podczas zastygania lawy, odsłonięty najczęściej w obrębie kamieniołomów. Formy tego typu są charakterystyczne dla Pogórza Kaczawskiego (Pogórze Złotoryjskie). Najbardziej znane - Wielkie Organy Wielisławskie oraz Małe Organy Myśliborskie - są objęte ochroną prawną. Średnica słupów wynosi najczęściej ok. 20-30 cm, ale gdzieniegdzie przekracza $50 \mathrm{~cm}$. Formy te są zazwyczaj cztero- i pięciokątne, a rzadziej trój- i sześciokątne. Występują także słupy nieprawidłowe (Janeczek, Kozłowski, Żaba, 1991) (fot. 4).

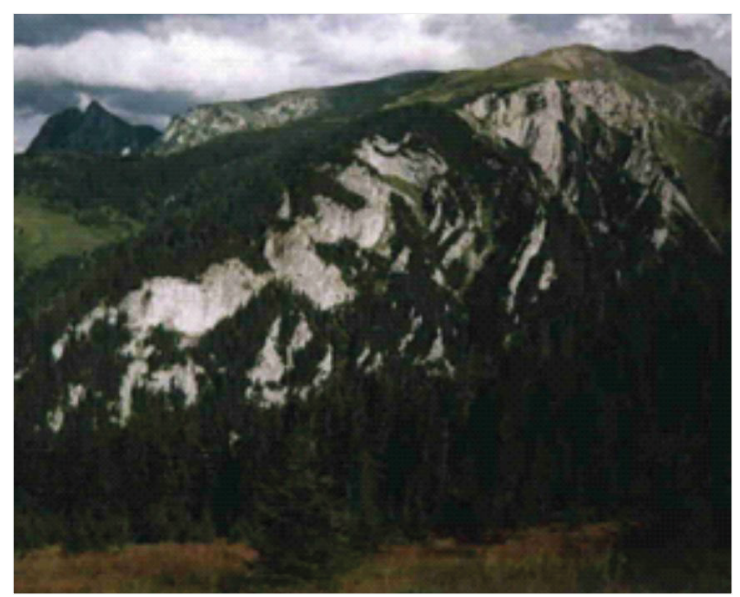

Fotografia 4. Widok na zbocze Organów w Dolinie Kościeliskiej (Tatry) Źródło: S. Bernat

- organy tektoniczno-wietrzeniowe - forma reliefu ścian skalnych o strukturze fałdowej (płaszczowinowej), złożonej ze stromo (prawie pionowo) nachylonych warstw o zróżnicowanej odporności. Odsłonięcie ich na powierzchni spowodowane jest działalnością czynników naturalnych (m.in. wiatru, wody, temperatury powietrza). Dotychczas znanym przykładem tego typu form jest wschodnie zbocze Doliny Kościeliskiej w Tatrach Zachodnich, gdzie fałd synklinalny organów, stanowiący północną część płaszczowiny Czerwonych Wierchów - zbudowanej $\mathrm{Z}$ wapieni i dolomitów triasowych i jurajskich - nasunięty jest na kredę autochtoniczną. Łatwiej wietrzejące dolomity tworzą żleby, wapienie zaś są widoczne w postaci żeber (Bac-Moszaszwili, Gąsienica-Szostak 1990; Kotański, 1971) (fot. 5). 


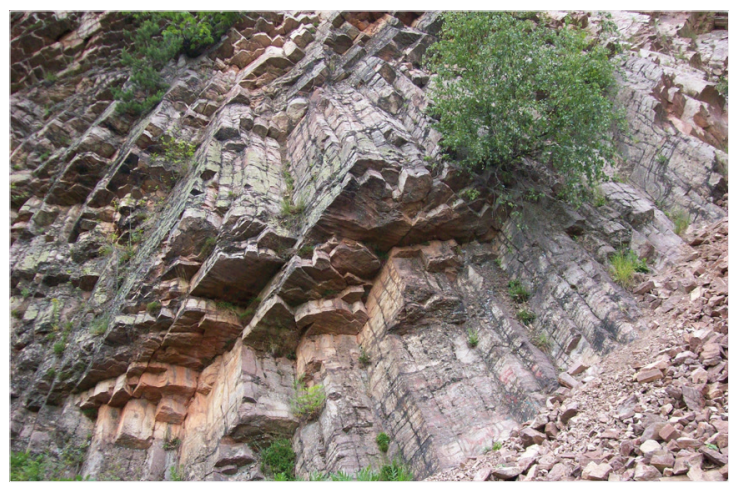

Fotografia 5. Organy Wielisławskie Źródło: S. Bernat

Przedmiotem zainteresowania zarówno geografa, jak i krajoznawcy mogą być także organy jako instrument pełen różnorodnych brzmień. W ostatnim czasie sprzyja temu utworzenie w Polsce kilku szlaków organowych, będących rodzajem ścieżek kulturowych, których główną ideą jest promocja organów i muzyki organowej jako elementów dziedzictwa kulturowego, materialnego i duchowego. Najstarszy z nich to Lubuski Szlak Organowy - obejmujący 18 kościołów w województwie lubuskim, leżących na trzech ścieżkach tematycznych dotyczących wybitnych budowniczych organów (Wrota lubuskie, 2019). Poza tym na terenie województwa warmińsko-mazurskiego funkcjonuje "Szlak gotyckich świątyń i muzyki organowej południowych Mazur", obejmujący kościoły w Pasymiu i Dźwierzutach, gdzie dodatkowo organizowane są koncerty organowe na zabytkowych instrumentach (Przewodnik Pasym, 2019). Największy zasięg ma natomiast „Szlak organowy w Euroregionie Silesia", który został utworzony niedawno. W jego skład wchodzi 35 kościołów na terenie pogranicza polsko-czeskiego, gdzie bogate są tradycje budownictwa organowego, obecne w licznie zachowanych zabytkowych instrumentach (Parafia Nowa Cerkiew, 2019). Oprócz prezentacji organów, promowane są zabytki sakralne regionu. Poza tym wspomnieć należy, że w kilku świątyniach na terenie województw kujawsko-pomorskiego i małopolskiego pod hasłem "szlak organowy" organizowane są koncerty organowe.

Przedmiotem zainteresowania krajoznawcy i geografa powinno być m.in. uchwycenie różnorodności instrumentów organowych, typowych dla określonych obiektów. W szczególności, z naukowego punktu widzenia, ważne jest rozpoznanie prawidłowości w ich rozmieszczeniu i dostrzeżenie regionalnych cech charakterystycznych. 
Organy mogą być interesujące tak dla krajoznawcy, jak i dla geografa jako element krajobrazu dźwiękowego. Są bowiem źródłem różnorodnych brzmień, stanowiących trwały element lokalnego krajobrazu dźwiękowego, „obecnym w pamięci mieszkańców, kształtującym świadomość foniczną miejsca zamieszkania (również poczucie tożsamości, lokalnej dumy) i mającym realny wpływ na przestrzeń dźwiękową otoczenia" (Losiak, 2017, s. 15). Skojarzenie z muzyką organową mogą wywoływać też rzeźby lub instalacje znajdujące się poza budynkami, związane m.in. z tradycją festiwali organowych (fot. 6, 7). Bardzo ciekawa, aczkolwiek wzbudzająca kontrowersje, jest instalacja "Grające organy” W. Hasiora, zamontowana w 1966 r. na przełęczy Snozka, w miejscu znanym z pięknych widoków na Zbiornik Czorsztyński, Pieniny i Tatry (fot. 8). Artystycznym zamierzeniem twórcy była realizacja wizji organów "grających wiatrem" ku pamięci wszystkich ofiar wojny. Jednak wbrew koncepcji Hasiora piszczałki nie zostały zamontowane, u podnóża rzeźby zaś pojawiła się tablica z napisem „Wiernym synom ojczyzny poległym na Podhalu w walce o utrwalenie władzy ludowej". Niekonserwowany od lat monument rdzewiał i zagrażał zwiedzającym. Usunięcia rzeźby domagało się kilka

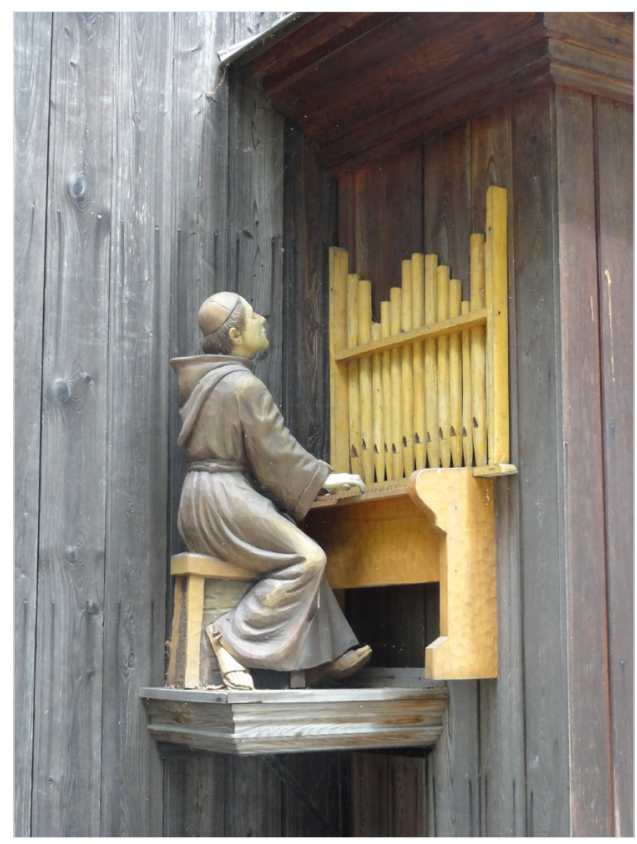

Fotografia 6. Rzeźba na ścianie kościoła w Bardzicach k. Radomia Źródło: S. Bernat 


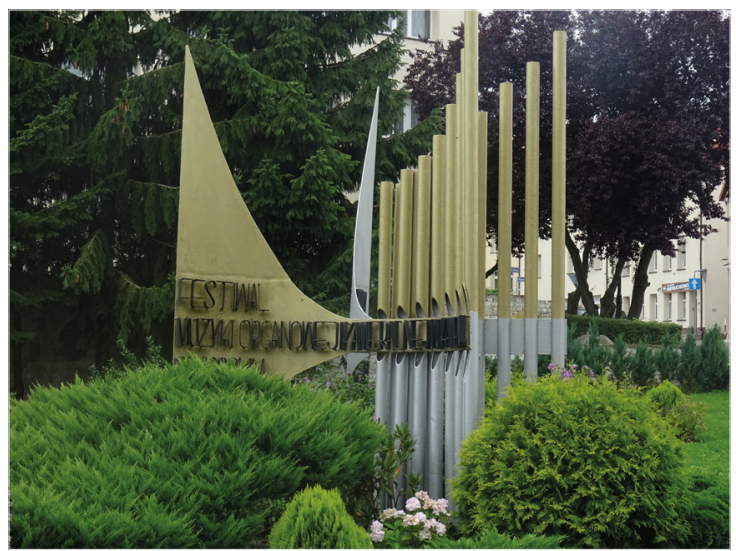

Fotografia 7. Instalacja w Kamieniu Pomorskim Źródło: S. Bernat

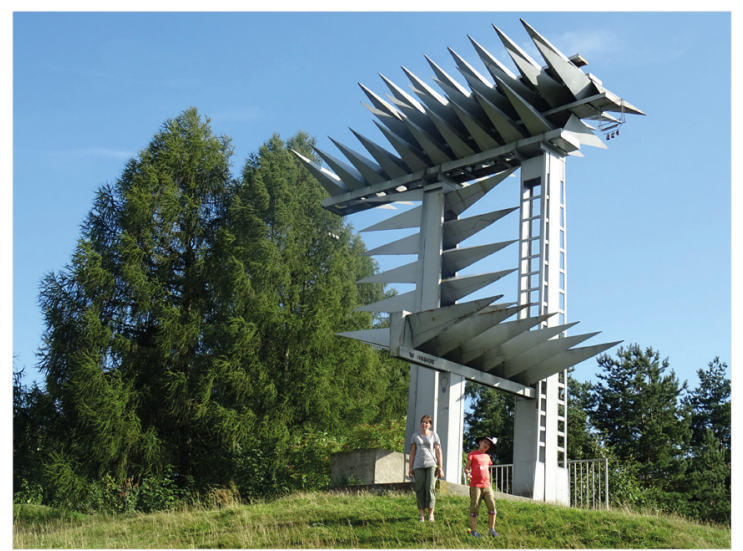

Fotografia 8. „Grające organy” na przełęczy Snozka Źródło: S. Bernat

stowarzyszeń, określając pomnik jako symbol władzy komunistycznej. W obronie dzieła stanęli m.in. artyści, zwracając się do władz gminy Czorsztyn o zmianę funkcji z upamiętniającej na edukacyjną i artystyczną. W 2010 r. na zlecenie władz gminy Czorsztyn i Fundacji Rozwoju Jeziora Czorsztyńskiego rozpoczął się remont „Organów”, mających w zamierzeniu stać się atrakcją turystyczną. $Z$ tablicy u podnóża instalacji skuto kontrowersyjną inskrypcję, elementy metalowe odnowiono i z powrotem zamontowano na pierwotnym miejscu (Podhale24.pl, 2019).

Wspomnieć jeszcze należy, że wyjątkową grającą instalacją są tzw. "organy morskie”, zlokalizowane w chorwackim mieście Zadar 
(CroLove.pl, 2019). Zasada działania tego nietypowego instrumentu jest podobna jak w przypadku tradycyjnych organów. Powietrze przepychane jest ciśnieniem wody przez system rur, osadzonych pod kamiennymi schodami nadmorskiej promenady. W każdej z rur ulokowane są gwizdki, które odgrywają siedem akordów w pięciu tonacjach. W momencie kiedy fala wtłacza do rur wodę, z gwizdków wydobywa się wyjątkowy dźwięk. Instrument stanowi atrakcję turystyczną i kształtuje tożsamość miejsca.

\section{Podsumowanie}

Zarówno w geografii, jak i w krajoznawstwie szczególną rolę odgrywa rozpoznanie, w jaki sposób człowiek doświadcza krajobrazu jako efektu oddziaływania przyrody i kultury. W upowszechnieniu takiego podejścia należy podkreślić szczególną rolę K.H. Wojciechowskiego, którego rozprawa habilitacyjna dotycząca wartości estetycznych krajobrazu ukazała się w okresie, kiedy polscy geografowie prowadzili specjalistyczne badania przede wszystkim nad strukturą i funkcjonowaniem środowiska przyrodniczego. Tenże badacz akcentował zaś, że „,[...] jeśli badania geograficzne mają rozwijać się tak, aby nie pozostawać w tyle za rozwojem cywilizacyjno-społecznym, to nie można rezygnować z prób działania na terenach pogranicza wielu dyscyplin badawczych" (Wojciechowski, 1986, s. 38), co udowodnił, podejmując problematykę doświadczania krajobrazu usytuowaną na pograniczu nauk, ale bazującą na podejściu humanistycznym w geografii.

Zwrócenie uwagi na przedmiot ludzkiego doświadczenia, jakim jest krajobraz postrzegany multisensorycznie, pozwala na odkrywanie niezwykłości w tym, co zwyczajne, skłania do zainteresowania problemami codzienności, zbliża do spojrzenia na rzeczywistość z perspektywy zwykłego człowieka. Ze względu na fakt, że geografia jest dyscypliną na pograniczu nauk przyrodniczych i społecznych, zajmujący się nią badacze, przyjmując perspektywę humanistyczna, mogą podnieść świadomość społeczna, dotyczącą jej użyteczności. Rozwija bowiem umiejętność „rozumienia świata” i daje poczucie jedności człowieka i przyrody, odpowiedzialnych za różnorodność krajobrazów Ziemi. Nie oznacza to, że czysto naukowe podejście analityczne jest niepotrzebne. Oba wzajemnie się uzupełniają i umożliwiają poznawanie świata. Konieczna jest zatem wzmożona świadomość naszych własnych doznań geograficznych i dążenie do przekazania innym, jakie znaczenie ma 
zachwyt nad konkretnymi miejscami. Docenianie roli doświadczenia w poznaniu stwarza zatem perspektywę rozwoju nie tylko samej geografii, ale także krajoznawstwa.

\section{Bibliografia}

Bac-Moszaszwili, M., Gąsienica-Szostak, M. (1990). Tatry Polskie. Przewodnik geologiczny dla turystów. Warszawa: Wydawnictwo Geologiczne.

Bartkowski, T. (1985). Nowy etap dyskusji nad pojęciem krajobrazu. Czasopismo Geograficzne, 56 (1), 73-79.

Bernat, S. (2001). Organy w muzyce i przyrodzie. Geografia w szkole, 2, 109-114.

Cosgrove, P. (2003). Landscape and the European sense of sight-eying, nature. W: K. Anderson, M. Domosh, S. Pile, N. Thrift, Handbook of cultural geography. Londyn: SAGE.

CroLove.pl (2019). Pobrano z: https://crolove.pl/morskie-organy-w-zadarze/ (18.09.2019).

Drzał, M. (1961). Kras w kredzie w Mielniku nad Bugiem. Biuletyn Instytutu Geologicznego, $169,241-245$.

Dziewiecki, M. (2013). Od urwisa do bohatera. Warszawa: Wydawnictwo eSPe.

Europejska Konwencja Krajobrazowa. Dz.U. 2006, nr 14, poz. 98.

Frydryczak, B. (2013). Krajobraz. Od estetyki the picturesque do doświadczenia topograficznego. Poznań: PTPN.

Granö, J.G. (1929/1997). Pure geography. Baltimore: Johns Hopkins Press.

Janeczek, J., Kozłowski, K., Żaba, J. (1991). Zbieramy minerały i skały. Przewodnik po Dolnym Śląsku. Warszawa: Wydawnictwo Geologiczne.

Kolbuszewski, J. (1985). Krajobraz i kultura. Sudety w literaturze i kulturze polskiej. Katowice: Wydawnictwo Śląsk.

Konstytucja o liturgii świętej (2020). Pobrane z: http://ptm.rel.pl/files/swii/139-sacrosanctum-concilium.pdf (23.09.2020).

Kotański, Z. (1971). Przewodnik geologiczny po Tatrach. Warszawa: Wydawnictwo Geologiczne.

Kowalczyk, A. (1992). Badanie spostrzegania krajobrazu multisensorycznego - podstawa kształtowania obszarów rekreacyjnych. Bydgoszcz: Wydawnictwo Wyższej Szkoły Pedagogicznej w Bydgoszczy.

Kowalczyk, A. (2008). Preferencje dźwięków w krajobrazie. Prace Komisji Krajobrazu Kulturowego PTG, 11, 36-43.

Kunsky, J. (1956). Zjawiska krasowe. Warszawa: Państwowe Wydawnictwo Naukowe.

Landscapes and individual and social well-being (2003). European Landscape Convention Report on Theme of the 2003 Workshop. Strasburg: Council of Europe Strasbourg.

Landscape and sustainable development: Challenges of the European Landscape Convention (2006). Strasbourg: Council of Europe.

Losiak, R. (2017). Instrumenty muzyczne w pejzażach dźwiękowych - instrumentologia wobec „soundscape studies”. Audiosfera. Koncepcje - Badania-Praktyki, 2 (6), 11-19.

Maruszczak, H. (1964). Wycieczka na Roztocze. VIII Ogólnopolski Zjazd PTG. Przewodnik wycieczkowy. Lublin: [b.w.].

Nałkowski, W. (1910). Krajoznawstwo i jego stosunek do geografii. Ziemia, 2, 1-20.

Parafia Nowa Cerkiew (2019). Pobrano z: http://www.parafianowacerekwia.pl/nc/images/ folder.pdf (18.09.2019). 
Pociej, B. (1995). Jan Sebastian Bach i jego muzyka. Warszawa: Wydawnictwa Szkolne i Pedagogiczne.

Podhale24.pl (2019). Pobrano z: http://podhale24.pl/aktualnosci/artykul/13153/Kluszkowce_odnowione_8222Organy8221_Hasiora_graja_na_Snozce_zdjecia.html (18.09.2019).

Przewodnik Pasym (2019). Pobrano z: http://przewodnik.pasym-parafia.pl/ (18.09.2019).

Pulina, M. (1999). Kras. Formy i procesy. Katowice: Wydawnictwo Uniwersytetu Śląskiego.

Relph, E. (1989). Doznania geograficzne a bycie w świecie. Fenomenologiczne pochodzenie geografii. Przeglad Zagranicznej Literatury Geograficznej, 2, 51-75.

Richling, A., Solon, J. (2011). Ekologia krajobrazu. Warszawa: Wydawnictwo Naukowe PWN.

Rodaway, P. (1994). Sensous geograhies. Body, sense and place. Londyn: Routledge.

Rzechowski, J. (1962). Kopalne formy krasowe z kamieniołomu w Rejowcu. Kwartalnik Geologiczny, 6, 109-123.

Saint-Exupéry, A. (2013). Mały Książę. Warszawa: Wydawnictwo Literackie MUZA SA.

Sawicki, L. (1909). Geografia a krajoznawstwo. Odczyt wygłoszony na posiedzeniu Towarzystwa Krajoznawczego w Warszawie dnia 10 listopad 1909 roku. Warszawa: Drukarnia L. Bogusławskiego.

Stasiak, A., Włodarczyk, B., Śledzińska, J. (2016). Wczoraj, dziś i jutro krajoznawstwa. W: A. Stasiak, J. Śledzińska, B. Włodarczyk (red.), Wspótczesne oblicza krajoznawstwa (s. 9-27). Warszawa: Wydawnictwo PTTK „Kraj”.

Tuan, Y.-F. (1979). Thought and landscape. The eye and the mind's eye. W: D.W. Meinig (red.), The interpretation of ordinary landscapes. Geographical essays (s. 103-125). Nowy Jork-Oksford: The Oxford University Press.

Tuan, Y.-F. (1987). Przestrzeń i miejsce. Warszawa: Państwowy Instytut Wydawniczy.

Wilczyński, W. (1996). Geografia jako sztuka edukacji. W: M. Pulinowa (red.), Człowiek blizej Ziemi. O teoretycznych podstawach nauczania geografii i ich praktycznym zastosowaniu (s. 86-101). Warszawa: Wydawnictwa Szkolne i Pedagogiczne.

Wilczyński, W. (2011). Ideowe źródła i tożsamość geografii. Kraków: Wydawnictwo Naukowe Uniwersytetu Pedagogicznego.

Wojciechowski, K.H. (1986). Problemy percepcji i oceny estetycznej krajobrazu. Lublin: Wydawnictwo Uniwersytetu Marii Curie-Skłodowskiej w Lublinie.

Wojciechowski, K.H. (1994). O przydatności badań percepcji krajobrazu. Zeszyty Naukowe PAN, 9, 109-124.

Wojciechowski, K.H. (1999). Refleksje o istocie geografii. W: B. Domański, W. Widacki (red.), Geografia polska u progu trzeciego tysiąclecia (s. 41-44). Kraków: Uniwersytet Jagielloński.

Wojciechowski, K.H. (2008). Doświadczenie krajobrazu jako koncepcja naukowa J.G. Granö. Prace Komisji Krajobrazu Kulturowego PTG, 11, 22-28.

Wójcik, Z. (1959). Fosforyty Mielnika nad Bugiem. Przeglad Geologiczny, 4, 172-173.

Wrota lubuskie (2019). Pobrano z: http://wrotalubuskie.eu/PL/636/646/Lubuski_Szlak_ Organowy/k/ (18.09.2019).

\section{KRAJOBRAZ JAKO PRZEDMIOT DOŚWIADCZANIA W GEOGRAFII I KRAJOZNAWSTWIE}

Abstrakt: Celem artykułu jest wykazanie ważnej roli doświadczania krajobrazu w geografii i krajoznawstwie. Po opisaniu związku między krajoznawstwem i geografią scharakteryzowano problematykę percepcji krajobrazu. Następnie opisano przykład organów w krajobrazie jako zagadnienie, w którym doświadczanie krajobrazu odgrywa znaczącą 
rolę. Wykazano, że zwrócenie uwagi na przedmiot ludzkiego doświadczenia, jakim jest krajobraz postrzegany multisensorycznie, pozwala na odkrywanie niezwykłości w tym, co zwyczajne, codzienne, zbliża do spojrzenia na rzeczywistość z perspektywy zwykłego człowieka. Docenianie roli doświadczenia w poznaniu stwarza zatem perspektywę rozwoju nie tylko samej geografii, ale także krajoznawstwa.

Słowa kluczowe: krajobraz, percepcja, geografia humanistyczna, krajoznawstwo, organy.

\title{
LANDSCAPE AS EXPERIENCE \\ IN BOTH GEOGRAPHY AND REGIONAL AND CULTURAL STUDIES
}

\begin{abstract}
The purpose of the article is to demonstrate the importance of landscape as experience in both geography and regional and cultural tourism studies. After describing the relationship between geography and cultural tourism studies, the author discusses different aspects of landscape perception. Next, he presents images from the website "Geological Organs" confirming the significance of landscape as actually experienced. It was demonstrated that focusing on landscape, perceived with multiple senses, makes it possible to discover the unique in the everyday and to look at reality from the point of view of an ordinary person. Appreciating the role of experience in cognition creates development opportunities, not only for geography itself, but also for cultural tourism.
\end{abstract}

Keywords: landscape, perception, human geography, regional and cultural studies. 